\title{
XXII. Description of a balance level, useful for laying out land for irrigation, for roads, and for other purposes
}

\section{Mr. Richard Drew}

To cite this article: Mr. Richard Drew (1808) XXII. Description of a balance level, useful for laying out land for irrigation, for roads, and for other purposes, Philosophical Magazine Series 1, 31:122, 120-121, DOI: $10.1080 / 14786440808563865$

To link to this article: http://dx.doi.org/10.1080/14786440808563865

曲 Published online: 18 May 2009.

Submit your article to this journal $\pi$

ЏII Article views: 2

Q View related articles $₫$ 


\section{$[120]$}

XXII. Description of a Balance Level, useful for laying out Land for Irrigation, for Roads, and for other Purposes. By Mr. Richand DRew, of Great Ormond Street*,

$\mathrm{H}_{\mathrm{FP} w}^{\mathrm{SIR},}$

HEREwith you will receive a balance level, of my invention, which have satisfactorily used on several gentlemen's estates in Devonshire, where 1 have been employed to drain and carry water to irrigate meadow land. I have made several for persons in that county, whuse employment is to crain and irrigate land, and they have found it to answer their purpose better than the spirit or water level, it being more portable and ready to the sight.

I have lately used it on $\mathrm{Mr}$. Satterley's farm, at Hastings, to carry the water of his closes over several acres of dry ground. Dr. De Salis, who has seen it, advised me to send it to the Society of Arts, \&c., that they inight judge of its merits. $\quad I \mathrm{am}$, sir, your obedient servant,

London, Dec. 5, 1804.

Richard Drew.

To the Secretary of the Society of Arts, \&c.

Explanation of the Method of using the Instrument.

Set it on a triangular staff, and point it at the object staff, which is held by another person at a distance; move the level on the joint, until the inner tube plays clear within the outer tube. Look through the sights, and observe the object staff which the person holds, let him move the slide on the staff until you see the hair cut the middle of the slide, on which there is a black line, then turn the level round, and look through the sights, you will then see if the hair cuts the middle of the slide as before, which if it does, it will be level, but if there be a difference in both ends, the person who holds the staff must set the slide to half that difference. You are then to adjust the level by turning with

* Fron Transactions of the Society for the Encouragement of Arts, Manufactures, and Commerce, for 1807 . - Ten guineas were voted to Mr. Drew, by the Society, for this communication. 
a key the screw which moves the balance contained in the bottom of the inner tube.

Certificates from Mr. J. W. Gooch, Mr. Charles Layton, and Mr. Benjamin Holmes, testify that they have seen in use the level invented by Mr. Richard Drew, and that the business is done by it with accuracy and dispatch.

Reference to the Engraving of Mr. Richard Drew's Balance Level. Plate IV., Fig. 1, 2, 3, 4.

Fig. 1. The balance level, mounted on a ball and socket joint, with a tube, $a$, to fix on a stand.

Fig. 2. A section, $b l c c$ two tubes of tin which slide on a short tube, $d d$, placed in the middle, and having an iron wire soldered round it to stiffen it, and to serve as a shoulder.

$e e$ Two eye-pieces, with glass in both, one at each end, and sliding into the tubes $b$ and $c$.

$f f$ The balance level, harging by a sort of staple $g$, on a point fixed upright on the middle of the bar $h$ (shown in Fig. 3), which is fastened across the tube $d$.

$i i$ Two eye-pieces sliding into the ends of the level $f f$, and having a narrow slit horizontally across the middle, with a hair before each, shown by the dots $h h$.

$k$ An adjusting screw, which acts by drawing the piece $m$, (which moves in a dove-tail slide,) in one end of the tube.

$n$ The key-hole through which the screw is turned.

Fig. 4. An end view of the case and level, showing the eye-pieces $i$ and $e$, one within the other.

XXIII. Description of a new Method of rearing. Poultry to Advantage. By Mrs. HanNain D'Oyley, of Sion Hill, near Northallerton*.

$\mathbf{I}_{\text {BEG leave to communicate a most desirable method of }}^{\text {sir, }}$ rearing poultry, which I have proved by experience. The oconomy and facility with which it may be performed,

* From Transactions of the Society for the Encouragement of Arts, Manufactures, and Commerce, for 1807. The silver medal of the Society was voted to Mrs. D'Oyley for this communication.

would, 